\title{
Impact of Interaction Between the Board of Directors and the Reputation of the Audit on the Performance of Companies: Study on the Tunisian Context
}

\author{
Emna Boumediene \\ Associate professor, Higher Institute of Accountancy and Corporate Management \\ University of Manouba, Campus Universitaire 2010, Manouba, Tunisia \\ E-mail: emna_boumediene@yahoo.fr
}

Received: October 18, 2018 Accepted: November 13, 2018 Published: November 23, 2018

doi:10.5296/ijafr.v8i4.13956

URL: https://doi.org/10.5296/ijafr.v8i4.13956

\begin{abstract}
This research aims to test the impact of the interaction between the external audit reputation and the characteristics of the board of directors on the firm performance. Hence, we have tried to test the hypothesis of Williamson (1983) in the Tunisian context.

The results obtained in the empirical analyses show a significantly negative effect of the interaction between the external audit reputation and the board independence of the financial performance of the firm. This result reveals the substitution effect between these two mechanisms.
\end{abstract}

Keywords: External audit, Board size of directors, Return on asset, Regression analysis

\section{Introduction}

Financial scandals and recent bankruptcies of several firms in the United- States and Europe have challenged the corporate governance, as well as its relevance and effectiveness. Investors, backers, shareholders and financial analysts have changed their perception of the corporate governance quality and its role to insure information transparency and to protect their interest. That's why a review of corporate governance has become a priority for different stakeholders.

As a consequence of these scandals, an interest is granted to the external audit and its quality. In fact, unexpected bankruptcies have put the emphasis on the opportunistic behaviour of 
managers. To cope with these practices, the external audit forms a control mechanism that aims for the credibility and the transparency of the disclosed information.

Thus, according to Jensen and Meckling (1976), the position of external audit is at the core of the agency relation between managers and shareholders. The agency theory considers the use of external audit as a mean of mitigating the opportunistic behaviour of managers. According to Ika and Ghazali (2012) the agency conflicts constitute a source of deterioration in the quality of financial information they impact the information asymmetry the sincerity of financial statements.

Roy (1996) highlights that by reducing conflicts, the external audit improves the firm performance. Likewise, the board of directors affects performance (Abdurrouf, 2010).

It's in this context that our research aims to study the impact of the external audit reputation and the directors' board on the firm's financial performance.

Some research has focused on behaviors that may affect the reputation of the audit. Herrbach (2010) shows that the psychological contract and emotional engagement of senior auditors affect the quality of the audit. By characterizing the relationship between the auditor and the audit firm as a "psychological contract", the researcher determines the elements of the psychological contract that determine the performance of team members. In this context, $\mathrm{Li}$, Qi, Tian, and Zhang (2017) emphasize the usefulness of disclosing the identity and personal information of auditors to investors and regulators to ensure better audit quality and improve the performance of the firm.

Then, we will try to examine the impact of the interaction between:

The external audit reputation and the directors board independence on the firm's financial performance.

The external audit reputation and the directors board size on the firm's financial performance

Consequently, we will try to respond to this question: what is the impact of the interaction between board of directors and the external audit reputation on the financial performance in the Tunisian context.

Thus, our purpose is to firstly review the effect of board of directors' characteristics on performance. Then, we examine the interaction between the external audit reputation and the board of directors on the firm's financial performance.

\section{Literature Review and Development of Hypothesis}

According to Gul, Wu, Yang (2013), the individual characteristics of the auditor has a significant effect on the quality of the audit. These attributes are related to his level of training, his membership of a Big four, his experience in the firm and even his political affiliation. He adds that the improvement of audit quality is correlated with an increase in the performance of Chinese companies. 


\subsection{Outside Directors Board and Financial Performance}

According to Jensen (1993) "The board, at the apex of the internal control system, has the final responsibility for the functioning of the firm. Most importantly, it sets the rules of the game for the CEO. The job of the board is to hire, fire, and compensate the CEO, and to provide high level counsel." Regarding its role, Fama (1980) considers that the board of directors is a vital mechanism within the big firms. In another way, Jensen and Meckling(1976) consider the board of directors as a reducing factor of conflicts of interests and agency costs. The effectiveness of the control role of the board is determined by its independence, size, duality and the nature of its members. Thus, Vafeas (1999) considers that the board quality is based on three facets, namely the proportion of external directors, their independence and the occupation of the management position.

Tepalagul and Lin (2014) identified four threats to the independence of the auditor, namely, the importance of the client, other services provided other than auditing, the auditor's mandate and membership in the auditor of one to audit firms.

The agency theory emphasizes on the importance of the presence of external auditors in the board. In fact, according to Fama (1980), the inclusion of external directors improves the flexibility of the board. Gilson (1990) define the external directors as members who don't have any direct or indirect relation with the firm, i.e. neither family ties nor business activities with the company. In this way, Charreaux (1997) underlines the influence of external directors on the board effectiveness and therefore on the firm performance. Cotter, Shivadasani and Zenner (1997) have shown the importance of the externals directors' role on the control of agency conflicts. In this direction, Weisbach (1988) states that the higher the proportion of external directors is the greater is the convergence between directors and shareholders' interests. In fact, the board of directors is likely to be independent that if the proportion of external directors is higher. This idea is also supported by John and Snebet (1998) who highlight that the board independence relies on its composition which should be characterized by a significant presence of external directors.

In this context, Jiraporn and al. (2018) have observed more than 14,000 observations over 18 years and concluded that companies that are forced to increase the independence of the board of directors, under the Sarbanes-Oxley Act (SOX) are much less likely to use a Big four auditor.

Similarly, Weisbach (1988), stated that the board effectiveness in exercising control and preserving shareholder's wealth is influenced by the proportion of outside directors. Different corporate governance researches have been emphasized on the importance of board independence as a tool reducing the discretionary authority and the opportunism of managers.

Several researches have shown the importance of the board of directors and its independence in the functioning of the firm and more particularly in achieving and improving its performance (Alexander and al. 2000).Vo and Nguyen (2014), Palmberg (2015) and Issarawornrawanrch (2015) find a positive relationship between the proportion of independent directors and firm performance. 


\section{MlMacrothink}

International Journal of Accounting and Financial Reporting

ISSN 2162-3082

2018, Vol. 8, No. 4

Omri (2003) confirm that the presence of outside directors forms an advantage for the firm. In fact, the latter can benefit from specific skills and expertise, and essentially from the professional and relational network of directors that can create possible profitable opportunities and investments for the firm (Kor and al., 2008). Likewise, in an American context, Baysinger and Buttler (1985) have shown that the presence of external directors has a positive effect on the firm's performance. They argued that firms with high levels of outside directors in the board have sustained high levels of performance measured by the ROE.

Vintila and al. (2015) and Bhagat and Bolton (2013) find that the relationship between the proportion of non-executive board members and firm performance is negative.

At the outcome of these different researches, we suppose that:

H1. The presence of outside directors in the board has a positive effect on the financial performance of the firm.

\subsection{The Board Size and Financial Performance}

Otherwise, the size of the board of directors, which is defined as the number of directors within the board, is a crucial characteristic of the board. Different researches have putted the emphasis on the importance of the board size, and have shown that the size has an influence on the effectiveness and the functioning of the board of directors.

In other words, the size affects the success of the board in carrying out assigned missions and tasks. In this way, Omri and Mehri (2003) argue that increasing board size improves control activities which reduces the conflicts of interest and consequently improves the firm performance.

On the other hand, some researchers recommend reducing the board size in order to improve firm performance. When a board becomes very large, it becomes difficult to coordinate and consequently to treat and resolve strategic problems of the organisation (Sanda and al. , 2010).In this context, Lipton and Lorsh (1992) confirm that large boards are less effective and easier to control. In fact, problem-solving and coordination costs are very important in large boards which make difficult the decision-making process. For these reasons, researchers in corporate governance show that small boards are more likely to improve the firm performance and value.

In Tunisia, the legislator states that public limited companies are required to create a board of directors containing at least three members. In fact, the clause 189 of the commercial companies' law indicates that the public limited company is managed by a board of directors composed of at least three members and twelve members at the most. Then, we adopt the following hypothesis:

$\mathrm{H} 2$. The board size has a negative effect on the financial performance of the firm.

\subsection{The Duality and Financial Performance}

Since, the concentration of management and control decisions in the hands of one person can be detrimental to the effectiveness of the board in its oversight role (Kajola, 2008). This 
situation generates conflicts of interests and increasing agency costs. To cope with these inconveniences, the agency theory suggests the separation between these two positions. In this regard, Sanda and al. (2010) state that firms that proceed to this separation improve their performance. In this way, Rechner and Dalton (1991), Rutledge and al. (2016) argue that the dual structure, when the CEO is also the chairman of the board of directors, has a negative effect on the firm performance. In fact, the detention of these two roles by the same person reduces his objectivity and can drive the manager to work on his own interest by exploiting the corporate resources as personnel benefits.

Thereby, the following hypothesis can be formulated:

H3. Duality has a negative effect on the financial performance of the firm.

\subsection{The Interaction of External Audit Reputation and the Board Independence with Financial Performance}

According to Jensen and Meckling (1976) and Watts and Zimmerman (1983), the external auditor position is at the core of the agency relation between managers and shareholders. In this case, the agency theory suggests that the use of external audit as a mean to reduce the possibilities of manipulating accounting data by controlling conflicts and mitigating information asymmetry in order to guarantee the information quality.

This mechanism is a way to manage the relationship between shareholders and managers, which positively affects the firm performance.

In general, literature looks at two crucial characteristics influencing the choice of an external auditor: size (De Angélo, 1981) and reputation (Klein, 2002) of the audit firm.

Otherwise, the use of an external auditor with a good reputation is justified by the research for a high-quality audit reducing the information asymmetry and consequently the opportunism of managers which leads to relevant information reflecting the real situation of the firm. In this case, Klein (2002) considers reputation as an indicator for a high audit quality.

In fact, audit firms with a good reputation provide good audit services by resisting to customers pressures. According to Willenborg (1999), the nomination of an auditor with a good reputation reflects the quality of the disclosed information. Consequently, the external audit with a good reputation enables to protect the firms' interest and to improve its performance.

Additionally, different researches, like Pitman and Fortin (2004), support the membership to an international network of audit firm as a measure for the auditor reputation. These researches have shown that the audit service provided by these firms is a high quality audit.

Consequently, being certified by a big four audit has a positive effect on firm performance. In this context, Krishnan (2003) has shown that firms that are audited by big are characterized by stock markets return and better future performance. 
In fact, researches have shown that big firms are characterized by the credibility of the disclosed information which guarantees the investors' confidence.

Despite the importance of the external audit and its role as a control mechanism, very limited studies have investigated the relation between auditor reputation and other corporate governance mechanism. Thus, O'sullivan and Diacon (1999) argue that there is a relationship between internal corporate governance mechanisms and the external audit. In fact, a good governance mechanism motivates firms to not insist to choose a high quality external control mechanism. Indeed, this effective internal mechanism is a guarantee of the information quality which does not compel firms, and more precisely shareholders, to choose an auditor with a good reputation. In other words, it's a substitution relationship Yeoh and Jubb (2001) and Fernandez and Arrondo (2005). Thereby, a negative association is observed between internal corporate governance mechanisms and the reputation of the external auditor.

In another way, the internal governance mechanism is essential for the functioning of the external mechanism, which leads also to a complementary relationship. Besides, Carcello and al. (2002) confirm that outside directors provide efforts to protect shareholders' interests. They attempt to choose auditors that provide high quality control services. In fact, Piot (2001) states that there is a positive relationship between outside directors an external audit. Thus, outside directors and external audit are considered as two complementary control mechanisms. Hence, the following hypothesis is formulated:

H4. The interaction between the external audit reputation and board independence has a negative effect on the financial performance of the firm.

\subsection{The Interaction of External Audit Reputation and the Board Size With Financial Performance}

Otherwise, Adjaoud et al (2007) have shown a complementary relationship between the board size and the external audit reputation. In fact, the external audit reputation and the board size complete each other in order to create the firm value. Thus, renowned external audit and large board of directors have a positive effect on firm performance. On the other hand, the researcher has found a negative association which reflects the substitute effect between board independence and external audit reputation. In fact, the interaction between board independence and external audit reputation has produced a negative effect on firm performance.

For this, we decided, in the case of our research, to examine the possible interaction between the board of directors and the external audit reputation in the Tunisian context, and investigate its impact on the firm performance. Besides, according to Nekhili and Cherif (2009) and Beasley (1996), large boards are less effective and generate conflict situations within the board. Likewise, Adams and al. (1997) have shown the existence of a complementary relationship between board size and external audit reputation to create firm value. Thus, we anticipate the existence of an interaction between board size and external audit reputation. In this way, we formulate the following hypothesis: 


\section{MIMacrothink}

International Journal of Accounting and Financial Reporting

ISSN 2162-3082

2018, Vol. 8, No. 4

H5. The interaction between external audit reputation and board size has a positive effect on the financial performance of firms.

\section{Research Method}

Our purpose is to study the effect of the interaction between board of directors and external audit reputation on the financial performance of firms. This research is conducted on a sample based on the Tunisian companies listed on the Tunisian stock exchange.

\subsection{Sample}

Our sample is based on 58 listed companies on the Tunisian stock exchange (TSE). Of all listed companies on the TSE, we have excluded financial institutions, namely, banks, insurance and leasing companies. We have proceeded to exclude such companies because they are regulated by specific standards. Then, we were able to select a sample of 30 listed companies observed from 2007 to 2011.

Variable measurements:

For the dependant variable, with reference to the studies conducted by Vafeas and Theodorou (1998), Klein (2002), Seifert, Morris and Bartkus (2003), we will select the return on assets (ROA) as a measure of the financial performance of the firm.

$$
\mathrm{ROA}=\text { Operating income/Total asset }
$$

Independent variables are those related to the audit quality, more precisely the auditor reputation, and those related to the board composition. Control variables related to size and leverage are presented in Table 1.

Table 1. Definitions and measurement of variables

\begin{tabular}{|c|c|c|c|}
\hline Variables & Definition & Measures & Authors \\
\hline \multicolumn{4}{|c|}{ Dependent variable } \\
\hline ROA & $\begin{array}{l}\text { The financial } \\
\text { performance of the } \\
\text { firm }\end{array}$ & $\begin{array}{l}\text { Operating income to } \\
\text { total assets ratio }\end{array}$ & $\begin{array}{l}\text { Klein (2002), Vafeas and } \\
\text { Theodorou (1998) Seifert, } \\
\text { Morris and Bartkus (2003) } \\
\text { Omri and Mehri (2003) }\end{array}$ \\
\hline
\end{tabular}

Independent variable

BS

Board Size

Total number of
directors on the board

Dechow, Sloan and sweeney (1995), Francis \& al. (1999) 
BI

Board Independence

Number of independent directors to the total number of directors

DUAL Board Duality

BIG

External reputation

audit A dichotomous variable that takes 1 if the firm is

A dichotomous variable that takes 1 if the CEO is the chairman of the board and 0 if otherwise audited by a big4 firm and 0 if otherwise

interaction

between

external audit external audit reputation and BS reputation and board size

$\begin{aligned} \mathrm{BIG}^{*} \mathrm{BI} & \begin{array}{l}\text { Interaction between } \\ \text { external audit } \\ \end{array} \\ & \text { reputation and BI }\end{aligned}$

BIG*DUAL Interaction between external audit reputation and

Interaction between external audit reputation and board independence

Interaction between external audit reputation and board
O'sullivan (2000), BeasleyandPetroni (2001), Piot (2001et 2005)

Sanda \& al (2010), Beasley (1996), Dechow\& al (1996)

(Defond, 1992), Francis and Wilson 1988)

(Beker\& al 1998), Agrawal and Chadha 2005)

Adjaoud and al (2007) duality

Adjaoud \& al (2007)

Adjaoud\&al(2007)

Control variables

\begin{tabular}{llll}
\hline Size & Firm size & $\begin{array}{l}\text { Logarithm of total } \\
\text { assets }\end{array}$ & $\begin{array}{l}\text { Agrawal and Knoeber } \\
(1996), \text { Klein (2002) }\end{array}$ \\
Debt & Leverage & Dept to total assets ratio & $\begin{array}{l}\text { Weir et al (2002), Ashbaugh } \\
\& \text { al (2006) }\end{array}$ \\
\hline
\end{tabular}

\subsection{The Statistical Model}

To examine the relation between the two corporate governance mechanisms and in order to respond to our research objectives we propose to estimate the following models:

The first model: This first model allows us to study the effect of board of directors on the 
financial performance of the firm.

$$
\mathrm{ROA}_{\mathrm{it}}=\beta 0+\beta 1 \mathrm{BS}_{\mathrm{it}}+\beta 2 \mathrm{BI}_{\mathrm{it}}+\beta 3 \mathrm{DUAL}_{\mathrm{it}}+\beta 4 \mathrm{BIG}_{\mathrm{it}}+\beta 5 \mathrm{Size}_{\mathrm{it}}+\beta 6 \mathrm{Debt}_{\mathrm{it}}+\varepsilon_{\mathrm{it}}
$$

With,

ROA: Return on Asset

BS: Board Size

BI: Board Independence

DUAL: Role duality of the CEO and the chairman of the board

BIG: External audit reputation

Size: Firm size

Debt: Leverage ratio

عit: Error term

The second model: By introducing the audit reputation variable "BIG" the following model enables to study the effect of the interaction between the board of directors and the auditor reputation.

$$
\begin{aligned}
\mathrm{ROA}_{\mathrm{it}} & =\beta_{0}+\beta 1 \mathrm{BS}_{\mathrm{it}}+\beta 2 \mathrm{BI}_{\mathrm{it}}+\beta 3 \mathrm{DUAL}_{\mathrm{it}}+\beta_{4} \mathrm{BIG}_{\mathrm{it}}+\beta_{5}\left(\mathrm{BIG}^{*} \mathrm{BS}\right)_{\mathrm{it}}+\beta_{6}\left(\mathrm{BIG}^{*} \mathrm{BI}\right)_{\mathrm{it}} \\
& +\beta_{7}\left(\mathrm{BIG}^{*} \mathrm{DUAL}\right)_{\mathrm{it}}+\beta_{8} \mathrm{Size}_{\mathrm{it}}+\beta 9 \mathrm{Debt}_{\mathrm{it}}+\varepsilon_{\mathrm{it}}
\end{aligned}
$$

With:

BIG*BS: Interaction between audit reputation and board size

BIG*BI: Interaction between audit reputation and board independence

BIG*DUAL: Interaction between audit reputation and duality

\section{Empirical Results and Discussion}

\subsection{Descriptive Statistics}

This analysis serves to present the descriptive characteristics of the variables and the sample relative to our study.

Descriptive analysis of quantitative variables

Table 2 presents the descriptive statistics of the quantitative variables.

Table 2. Descriptive statistics of the quantitative variables

\begin{tabular}{lllll}
\hline Variables & Mean & Standard deviation & Minimum & Maximum \\
\hline ROA & 0.051 & 0.076 & -0.164 & 0.226
\end{tabular}




$\begin{array}{lllll}\text { BS } & 8.817 & 2.146 & 4 & 12 \\ \text { BI } & 0.225 & 0.201 & 0 & 1 \\ \text { Size } & 7.755 & 0.434 & 6.116 & 9.198 \\ \text { Debt } & 0.466 & 0.276 & 0.007 & 1.804\end{array}$

The descriptive statistics shows that the mean of the ROA is $5.1 \%$ with a maximum of $22.6 \%$ and a negative minimum of $-16.4 \%$. Likewise, on average, the board size in our sample is formed with 9 members (8.817) in conformity with the commercial companies law which states that the number of directors sitting in the board of directors should vary between a minimum of 4 directors and a maximum of 12 directors. For the board independence, we notice that on average $22.5 \%$ of total directors are independent with a maximum of 1 and a minimum of 0 . This demonstrates that the board of directors of the Tunisian companies are characterized by a low level of independence. Results show also that on average Tunisian firms present a debt ratio of $46.6 \%$ which means that debts form a mean of $46.6 \%$ of all means of financing.

Descriptive analysis of qualitative variables

Table 3 presents the descriptive statistics of qualitative variables.

Table 3. Descriptive statistics of qualitative variables

\begin{tabular}{lll}
\hline Variables & Modality & Percentage \\
\hline Dual & 0 & $36.50 \%$ \\
& 1 & $63.50 \%$ \\
Big & 0 & $48.90 \%$ \\
& 1 & $51.1 \%$ \\
\hline
\end{tabular}

The analysis of the dichotomous variable Dual shows that $63.5 \%$ of companies in our sample opt to cumulate the functions of CEO and the chairman of the board of directors. This shows that the majority of these companies are dominated by the managers. This result can be explained by the fact that the majority of Tunisian firms are family owned companies. Furthermore, $51.1 \%$ of companies in our sample are audited by auditors belonging to Big 4 firms.

\subsection{Empirical Results of the Multivariate Analysis}

Before starting the logistic analysis, we will check the existence of a multicollinearity problem. This problem appears between the explicative variables of the study. In effect, a strong 


\section{Macrothink}

International Journal of Accounting and Financial Reporting

ISSN 2162-3082

2018, Vol. 8, No. 4

correlation between two independent variables can damage the results of the logistic analysis. To test this problem, we used the Pearson correlation matrix. With reference to the cat-off fixed by statisticians like Kenedy (1992), we have considered that two variables are correlated if the correlation coefficient is higher or equal to 0.8. The analysis of the Pearson correlation's coefficients shows the non-existence of a multicollinearity problem between the predefined variables.

Table 4. Pearson correlation matrix

\begin{tabular}{llllllll}
\hline & ROA & Big & BS & Dual & Size & BI & Debt \\
\hline ROA & 1 & & & & & & \\
Big & 0.065 & 1 & & & & & \\
BS & -0.058 & -0.001 & 1 & & & & \\
Dual & -0.075 & -0.104 & 0.084 & 1 & & & \\
Size & 0.085 & 0.184 & 0.037 & 0.116 & 1 & & \\
BI & -0.01 & 0.197 & 0.257 & 0.181 & 0.29 & 1 & \\
Debt & -0.506 & 0.257 & 0.191 & -0.007 & 0.104 & 0.096 & 1 \\
\hline
\end{tabular}

Moreover, this research is conducted on a sample of firms during a five-year period from 2007 to 2011. The data processing needs to take into account the temporal variability and the inter-individual variability. In fact, panel data present a problem of heterogeneity. In order to check the existence of this problem, we used the Fisher test.

Table 5. Fisher test

\begin{tabular}{llc}
\hline & Model 1 & Model 2 \\
\hline Statistic coefficient of Fischer & 12.98 & 14.36 \\
P-value & 0.0000 & 0.0000 \\
\hline
\end{tabular}

The table displays a significant $\mathrm{P}$-value $(\mathrm{P} \leq 5 \%)$, then we can conclude from this test that our sample present a heterogeneity problem. This leads us to opt for a fixed effect model or a random effect model. For this purpose, we proceed to the Hausman test. 


\section{1l Macrothink}

International Journal of Accounting and Financial Reporting

Table 6. Hausman test

\begin{tabular}{lll}
\hline & Model 1 & Model 2 \\
\hline Hausman Test & 40.29 & 284.26 \\
Probability & 0.0000 & 0.0000 \\
Specification model & Fixed effect model & Fixed effect Model
\end{tabular}

For model 1 and 2, the table displays a probability of $0.000<10 \%$ which implies that we have to choose the fixed effect model.

Otherwise, the Breusch-Bagan test (1979) enables to check the heteroscedasticity problem. The table shows a significant parameter of the Breusch-Pagan test at the level of $10 \%$ $(\mathrm{p}=0.0000<0.1)$. Thus, we can conclude the presence of a heteroscedasticity problem. To correct this problem, we have adopted the robust function in Stata.

Table 7. Breusch-Pagan test

\begin{tabular}{lll}
\hline & Model1 & Model 2 \\
\hline Breusch - Pagan test & 66.91 & 65.28 \\
Probability & 0.0000 & 0.0000 \\
\hline
\end{tabular}

In what follows, we will present the empirical regression results. For the first model, we raise a model $\mathrm{R}^{2}=0.1033$ and a significant F-ratio at the level of $1 \%$. Thus, our model is globally significant.

The results of table 8 confirm our first hypothesis which supposes that the presence of outside directors within the board of directors has a positive effect on the financial performance of the firm. In fact, BI presents a positive and significant coefficient at the level of $10 \%(\beta=$ 0.0584652 , $\mathrm{p}$-value $=0.078$ ). This result supports studies conducted by Baysinger and Buttler (1985), Kor and al. (2008) and Omri and Mehri (2003) which confirm that the board independence has a positive effect in the firm performance.

On another note, we notice a negative but non-significant relation between board size and firm performance $(\beta=-0.0007334$, $\mathrm{p}$-value $=0.780)$. This result leads us to reject our second hypothesis which supposes that the board size has a negative effect on the firm financial performance. The result does not converge with the findings of M'Hamid and al. (2011) and Zabri and al. (2016) that show a negative relation between board size and firm performance. Thus, it turns out that the smaller the board size is, the greater is its impact on the firm performance.

Otherwise, the coefficient associated to the variable Dual is positive but non-significant ( $\beta=$ 
$0.0016152, \mathrm{p}$-value $=0.915)$.

This result conducts us to reject the third hypothesis which stipulates that the board duality has a negative effect on performance. This does not converge with findings of Duru and al. (2016), Dogan and al., (2013) and Jensen (1993). In fact, these authors state that the distinction between the control and the management functions reduces agency costs and improve performance (Kajola and al. 2008).

Concerning control variables, the table shows a negative and significant relation between firm size and firm performance $(\beta=-0.0334451, p$-value $=0.003)$ at the level of $1 \%$. This result supports the findings of Black and al. (2006) which advance that small firms are more performant than large firms. The variable Debt shows a negative but non-significant coefficient $(\beta=-0.029509$, $p$-value $=0.333)$. Thus, this finding is not consistent with the study of Weir and al. (2002).

Furthermore, the regression results of the second model show a good association between the dependent variable ROA and the other independent variables. In fact, the R squared is equal to $23.69 \%$ and the $\mathrm{F}$ statistic is significant ( $\mathrm{prob}>\mathrm{F}=0.0000$ ).

In accordance with our first hypothesis, results of table 8 (2) show that the presence of independent outside directors within the boars has a positive effect on firm performance. In fact, the coefficient relative to the variable BI is positive and significant at the level of $5 \%(\beta=$ 0.1673548 , $\mathrm{p}$-value $=0.039$ ). This result is in accordance with the studies conducted by Black and al. (2006) which prove that the board independence has a crucial role in mitigating agency conflicts and thus contributes to improve the firm performance.

As a consequence, results shown in the table display a negative and significant relation between board size variable and financial performance of the firm. In fact, the coefficient associated to this variable is negative and significant at the level of $1 \%(\beta=-0.0403128, p$-value $=0.000$ ). This result confirms the result of Andres and Vallelado (2008) as well as our second hypothesis which stipulates that the board size has a negative effect on the firm performance.

Furthermore, board duality shows a positive but non-significant coefficient $(\beta=4.6806$, $\mathrm{p}$-value $=1.000$ ). This leads us to reject our third hypothesis which supposes that duality has a negative effect on the financial performance of the firm. This result is not in accordance with findings of Jensen (1993) and Kajola (2008) which states that the distinction between the function of $\mathrm{CEO}$ and the function of the chairman of the board reduces agency conflicts and improve the firm performance.

Concerning the combination of the variable Big*BS, we notice a negative but not significant coefficient $(\beta=-0.001032, \mathrm{p}$-value $=0.810)$. This leads us to reject our fourth hypothesis which stipulates that the interaction between external audit reputation and board size has a positive effect on the financial performance of the firm. This does not confirm with the results of Adjaoud and al. (2007) that demonstrate a positive effect of external audit reputation and board size on the firm performance. However these results show a complementary relation between the external audit reputation and the board size. In fact, these both control mechanisms go together to improve the firm performance. 
In another way, we were able to confirm our fifth hypothesis which stipulates that the interaction between external audit reputation and board independence has a negative effect on the financial performance of the firm. In fact, the coefficient related to this variable is negative and significant at the level of $5 \%(\beta=-0.1282094$, $p$-value $=0.027)$. This confirms the results of Adjaoud and al. (2007) as well as the substitution hypothesis of Williamsom (1983). In fact, board independence forms an effective control mechanism that substitutes the external audit. Additionally, this result is in accordance with the studies conducted by O'sullivan and Diacon (1999), Anderson and al. (1993) which state that firms with a good internal governance structure sacrifice external mechanisms such as the external audit.

Finally, we notice that the variable Big*Dual displays a positive but not significant coefficient $(\beta=0.010433$, $p$-value $=0.708)$. Thus, the fifth hypothesis is rejected. Hence, it seems that the interaction between external audit reputation and duality has no positive influence on firm performance. This does not confirm the studies conducted by Adjaoud and al. (2007), Ashbaugh and Warfield (2003), Beasley (1996) which suppose that in a duality case the board of directors is responsible for the engagement with high quality external auditors.

Table 8. Regression results

\begin{tabular}{|c|c|c|c|c|}
\hline & Model 1 & & Model 2 & \\
\hline & Coefficient & Signification & Coefficient & Signification \\
\hline Constant & 0.3303279 & $0.001 * * *$ & 0.3696374 & $0.000 * * *$ \\
\hline BS & -0.0007334 & 0.780 & -0.0403128 & $0.000 * * *$ \\
\hline BI & 0.0584652 & $0.078 *$ & 0.1673548 & $0.039 * *$ \\
\hline Dual & 0.0016152 & 0.915 & 4.6806 & 1.000 \\
\hline Size & -0.0334451 & $0.003 * * *$ & 0.0017894 & 0.573 \\
\hline Debt & -0.029509 & 0.333 & -0.0191134 & 0.509 \\
\hline Big & - & - & 0.0187089 & 0.645 \\
\hline Big*BS & - & - & -0.001032 & 0.810 \\
\hline Big*BI & - & - & -0.1282094 & $0.027 * *$ \\
\hline \multirow[t]{3}{*}{ Big*Dual } & - & - & 0,010433 & 0,708 \\
\hline & R2 Within = & $\mathrm{F}=$ & $\mathrm{R} 2 \mathrm{Within}=0.2369$ & $F=25.68$ \\
\hline & R2 Between = & $\mathrm{P}=$ & R2 Between $=0.0009$ & $\mathrm{P}=0.0000$ \\
\hline
\end{tabular}

*Significant at the level of $10 \%, * *$ Significant at the level of $5 \%, * * *$ Significant at the level of $1 \%$ 


\section{Conclusion}

This research aims to test the impact of the interaction between the external audit reputation and the characteristics of the board of directors on the firm performance. Hence, we have tried to test the hypothesis of Williamson (1983) in the Tunisian context.

The results obtained in the empirical analyses show a significantly negative effect of the interaction between the external audit reputation and the board independence the financial performance of the firm. This result reveals the substitution effect between these two mechanisms.

The contribution of this research is at two levels. The first contribution is the introduction of the external audit reputation as a governance mechanism and examine its impact on the firm performance. Thus, different studies concerning the external audit were interested to study the impact of governance mechanisms on the demand of a high quality audit. The second contribution of this research is to study the effect of an interaction between the external audit reputation and some internal corporate governance mechanisms, namely the board of directors, on the financial performance of the firm. In fact, the previous studies have focused solely on the relationship between performance and one of the governance mechanisms taken apart. Besides, this contribution lies in the examination of these different relations in the Tunisian context.

Like any research, this study has some limits relative to our sample size (only 30 companies) and the measurement of the audit quality which is taken into account through a study of its reputation.

Some future research could be conducted while taking into account these limits and where it will be possible to introduce other characteristics related to the board of directors and possible to test this problem in the banking sector.

\section{References}

Abdurrouf, M. D., Siddique, N., \& Abdur Rahaman, M. (2010). Good corporate governance principals and recommendations for good practices. Journal of Socio-Economic Research and Development, 7, 970-975.

Adams, M., Sherris, M., \& Hossain, M. (1997).The determinants of external audit costs in the New Zealand life insurance industry. Journal of International Financial Management and Accounting, 8(1), 69-86.

Adjaoud, F., Mamoghli, C., \& Siala, F. (2008). Auditor reputation and internal corporate governance mechanisms: Complementary or substitutable?. Review of Business Research, 8(1), 84-98.

Agrawal, A., \& Chadha, S. (2005). Corporate governance and accounting scandals. The Journal of Law and Economics, 48(2), 371-406. 


\section{MlMacrothink}

International Journal of Accounting and Financial Reporting

ISSN 2162-3082 2018, Vol. 8, No. 4

Agrawal, A., \& Knoeber, C. R. (1996). Firm performance and mechanisms to control agency problems between managers and shareholders. Journal of Financial and Quantitative Analysis, 31(3), 377-397.

Anderson, D., Francis, J. R., \& Stokes, D. J. (1993). Auditing, directorships and the demand for monitoring. Journal of Accounting and Public Policy, 12(4), 353-375.

Andres, P., \& Vallelado, E. (2008). Corporate governance in banking; the role of board directors. Journal of Banking and Finance, 32, 2570-2580.

Ashbaugh, H., \& Warfield, T. D. (2003). Audits as a corporate governance mechanism: Evidence from the German market. Journal of International Accounting Research, 2(1), 1-21.

Ashbaugh, H., Collin, D. W., \& Lafond, R. (2006). The effect of corporate governance on firms' credit rating. Journal of Accounting and Economics, 42, 203-243.

Baysinger, B. D., \& Butler, H. N. (1985). Corporate governance and the board of directors: Performance effects of changes in board composition. Journal of Law, Economics and Organization, 1(1), 101-124.

Beasley, M. S. (1996). An empirical analysis of the relation between the board of director composition and financial statement fraud. Accounting Review, 443-465.

Beasley, M. S., \& Petroni, K. R. (2001). Board independence and audit-firm type. Auditing: A Journal of Practice and Theory, 20(1), 97-114.

Becker, C. L., DeFond, M. L., Jiambalvo, J., \& Subramanyam, K. R. (1998). The effect of audit quality on earnings management. Contemporary Accounting Research, 15(1), 1-24.

Bhagat, S., \& Bolton, B. J. (2013). Director ownership, governance, and performance. Journal of Financial and Quantitative Analysis, 48(1), 105-135.

Black, B. S., Love, I., \& Rachinsky, A. (2006). Corporate governance indices and firms' market values: Time series evidence from Russia. Emerging Markets Review, 7(4), 361-379.

Carcello, J. V., Hermanson, D. R., Neal, T. L., \& Riley, R. A. (2002). Board characteristics and audit fees. Contemporary Accounting Research, 19(3), 365-384.

Charreau, G. (1997). Vers une théorie du gouvernement des entreprises. Le gouvernement des entreprises. Edition Economica, 421-469.

Cotter, F., Shivdasani, A., \& Zenner, M. (1997). Do independent directors enhance target shareholder wealth during tender offers. Journal of Financial Economics, 43(2), 195-218.

De Andres, P., Azofra, V., \& Lopez, F. (2005). Corporate boards in OECD countries: Size, composition, functioning and effectiveness. Corporate Governance: An International Review, 13(2), 197-210.

De Angelo, L. (1981). Auditor size and quality. Journal of Accounting and Economics, 3(2), 183-199. 


\section{I Macrothink}

International Journal of Accounting and Financial Reporting

ISSN 2162-3082

2018, Vol. 8, No. 4

Dechow, P. M., Sloan, R. G., \& Sweeney, A. P. (1995). Detecting earnings management. Accounting Review, 70, 193-225.

Dechow, P. M., Sloan, R. G., \& Sweeney, A. P. (1996). Causes and consequences of earnings manipulation: An analysis of firms subject to enforcement actions by the SEC. Contemporary Accounting Research, 13(1), 1-36.

Defond, M. L. (1992). The association between changes in client firm agency costs and auditor switching. Auditing, 11(1), 16-29.

Dogan, M., Bilge, L., Elitas, A., \& Veysel, Ö. S. (2013). The impact of CEO duality on firm performance: Evidence from Turkey. International Journal of Business and Social Science, $4(2), 149-155$.

Duru, A., Iyengar, R. J., \& Zampelli, E. M. (2016). The dynamic relationship between CEO duality and firm performance: The moderating role of board independence. Journal of Business Research, 69(10), 4269-4277.

Fama, E. F. (1980). Agency problems and theory of the firm. Journal of Political Economy, 88, 288-307.

Fernández, C., \& Arrondo, R. (2005). Alternative internal controls as substitutes of the board of directors. Corporate Governance: An International Review, 13(6), 856-866.

Francis, J. R., \& Wilson, E. R. (1988). Auditor changes: A joint test of theories relating to agency costs and auditor differentiation. Accounting Review, 663-682.

Francis, J. R., Maydew, E. L., Sparks, H. C. (1999). The role of Big 6 auditors in the credible reporting of accruals. Auditing: A Journal of Practice and Theory, 18(2), 17-34.

Gilson, F. C. (1990). Bankruptcy, boards, banks and block holders: Evidence on changes in corporate ownership and control when firm default. Journal of Financial Economics, 27(2), 355-387.

Gul, F., Wu, D., \& Yang, Z. (2013). Affect audit quality? Evidence from archival data. The Accounting Review, 88(6), 1993-2023.

Herrbach, O. (2010). Audit quality, auditor behavior and the psychological contract. European Accounting Review, 10(4), 787-802.

Ika, S. R., \& Ghazali, N. A. M. (2012). Audit committee effectiveness and timeliness of reporting: Indonesian evidence. Managerial Auditing Journal, 27(4), 403-424.

Issarawornrawanrch, P. (2015). The association between board of directors characteristics and firm performance: Empirical evidence from emerging market of Thailand. The Journal of Applied Business and Economics, 17(1), 54-65.

Jensen, M. C. (1993). The modern industrial revolution, exit the failure of internal control systems. Journal of Finance, 3, 831-880. 


\section{MlMacrothink}

International Journal of Accounting and Financial Reporting

ISSN 2162-3082

2018, Vol. 8, No. 4

Jensen, M. C., \& Meckling, W. H. (1976). Theory of the firm: Managerial behavior, agency costs and ownership structure. Journal of Financial Economics, 3, 305-360.

Jiraporn, P., Chintrakarn, P., Tong, S., \& Treepongkaruna, S. (2018). Does board independence substitute for external audit quality? Evidence from an exogenous regulatory shock. Australian Journal of Management, 43(1), 27-41.

Kajola, S. O. (2008). Corporate governance and firm performance: The case of Nigerian listed firms. European Journal of Economics, Finance and Administrative Sciences, 14(14), $16-28$.

Kataa, Y. (2014). Le conseil d'administration et la réputation de l'audit externe: Interaction et impact sur la performance financière des entreprises tunisiennes cotées. Mémoire de mastère de recherche en comptabilité, ISCAE.

Kennedy, P. (1992). A guide to econometrics. Basil Blackwell, Southampton.

Klein, A. (2002). Audit committee, board of director characteristics, and earnings management. Journal of Accounting and Economics, 33(3), 375-400.

Kor, Y., \& Misangyi, V. F. (2008). Outside directors industry-specific experience and firm's liability of newness. Strategic Management Journal, 29(2), 1345-1355.

Krishnan, G. V. (2003). Audit quality and the pricing of discretionary accruals. Auditing: A Journal of Practice \& Theory, 22(1), 109-126.

Li, L., Qi, B., Tian, G., \& Zhang, G. (2017). The contagion effect of low quality audits at the level of individual auditors. The Accounting Review, 92(1), 137-163.

Lipton, M., \& Lorsch, J. W. (1992). A modest proposal for improved corporate governance. The Business Lawyer, 59-77.

M'Hamid, I., Hachana, R., \& Omri, A. (2011). Diversité genre dans le conseil d'administration et performance des entreprises tunisiennes. Global Journal of Management and Business Research, 11(4), 93-101.

Nekhili, M., \& Cherif, M. (2009). Transactions avec les parties liées, caractéristiques de propriété et de gouvernance et performance des entreprises françaises. Comptabilité-Contrôle-Audit, 15(3), 55-89.

O'sullivan, N. (2000). The impact of board composition and ownership on audit quality: evidence from large UK companies. The British Accounting Review, 32(4), 397-414.

O’Sullivan, N., \& Diacon, S. (1999). Internal and external governance mechanisms: evidence from the UK insurance industry. Corporate Governance: An International Review, 7(4), 363-373.

Omri, A. (2003). Systèmes de gouvernance et performance des entreprises tunisiennes. Revue Française de Gestion, 142, 85-100. 


\section{Macrothink}

International Journal of Accounting and Financial Reporting

ISSN 2162-3082

2018, Vol. 8, No. 4

Omri, A., \& Mehri, B. (2003). Conseil d'administration et performance des entreprises tunisiennes. African Administrative Studies, 60, 95-111.

Palmburg, J. (2015). The performance effect of corporate board of directors. European Journal of Law \& Economics, 40(2), 273-292.

Piot, C. (2001). Agency costs and audit quality: evidence from France. European Accounting Review, 10(3), 461-499.

Piot, C. (2005). Auditor reputation and model of governance: A comparison of France, Germany and Canada. International Journal of Auditing, 9(1), 21-44.

Pittman, J. A., \& Fortin, S. (2004). Auditor choice and the cost of debt capital for newly public firms. Journal of Accounting and Economics, 37(1), 113-136.

Rechner, P. L., \& Dalton, D. R. (1991). CEO duality and organizational performance: A longitudinal analysis. Strategic Management Journal, 12(2), 155-160.

Rhoades, L., \& Eisenberger, R. (2002). Perceived organizational support: A review of the literature. Journal of Applied Psychology, 87(4), 698-714.

Roy, D. (1996). The demand for external auditing: size, debt and ownership influences:A replication and extension. Cahier de recherche 09, HEC Montréal, Université de Montréal.

Rutledge, R. W., Karim, K. E., \& Lu, S. (2016). The effects of board independence and CEO duality on firm performance: Evidence from the NASDAQ-100 index with controls for endogeneity. Journal of Applied Business \& Economics, 18(2), 49-71.

Sanda, A. U., Mikailu, A. S., \& Garba, T. (2010).Corporate governance mechanisms and firms' financial performance in Nigeria. Afro-Asian Journal of Finance and Accounting, 2(1), 22-39.

Seifert, B., Morris, S. A., \& Bartkus, B. R. (2003). Comparing big givers and small givers: Financial correlates of corporate philanthropy. Journal of Business Ethics, 45(3), 195-211.

Tepalagul, N., \& Lin, L. (2014). Auditor independence and audit quality: A literature review. Journal of Accounting, Auditing and Finance, 30(1), 101-121.

Vafeas, N., \& Theodorou, E. (1998). The relationship between board structure and firm performance in the UK. The British Accounting Review, 30(4), 383-407.

Vafeas. (1999). Board meeting frequency and firm performance. Journal of Financial Economics, 53(1), 113-142.

Vintila, G., Paunescu, R. A., \& Gherghina, S. C. (2015). Does corporate governance influences corporate financial performance? Empirical evidences for the companies listed on US markets. International Business Research, 8(8), 27-49.

Vo, D. H., \& Nguyen, T. M. (2014). The impact of corporate governance on firm performance: Empirical study in Vietnam. International Journal of Economics and Finance, 6(6), 1-13. 


\section{Mll Macrothink}

International Journal of Accounting and Financial Reporting

ISSN 2162-3082

2018, Vol. 8, No. 4

Watts, R. L., \& Zimmerman, J. L. (1983). Agency problems, auditing, and the theory of the firm: Some evidence. The Journal of Law and Economics, 26(3), 613-633.

Weir, C., Laing, D., \& McKnight, P. J. (2002). Internal and external governance mechanisms: their impact on the performance of large UK public companies. Journal of Business Finance \& Accounting, 29(5-6), 579-611.

Weisbach, M. (1988). Outside director and CEO turnover. Journal of Financial Economics, 20, 431-460.

Willenborg, M. (1999). Empirical analysis of the economic demand for auditing in the initial public offerings market. Journal of Accounting Research, 37(1), 225-238.

Williamson, O. E. (1983). Organization from residual claimants and corporate control. Journal of Law and Economics, 26, 351-366.

Yeoh, E., \& Jubb, C. A. (2001).Governance and audit quality: is there an association?. Working Paper, University of Melbourne, Australia.

Zabri, S. M., Ahmad, K., \& Wah, K. K. (2016). Corporate governance practices and firm performance: Evidence from top 100 public listed companies in Malaysia. Procedia Economics and Finance, 35, 287-296.

\section{Copyright Disclaimer}

Copyright for this article is retained by the author(s), with first publication rights granted to the journal.

This is an open-access article distributed under the terms and conditions of the Creative Commons Attribution license (http://creativecommons.org/licenses/by/4.0/) 